\title{
Normal lymphocyte responsiveness to lectins but impaired sensitivity to in vitro glucocorticoids in major depression
}

\author{
N. Wodarz ${ }^{1}$, R. Rupprecht ${ }^{1,2}$, J. Kornhuber ${ }^{1}$, B. Schmitz ${ }^{1}$, K. Wild ', H.U. Braner ${ }^{1}$ \\ and P. Riederer ${ }^{1}$ \\ ${ }^{\prime}$ Department of Psychiatry, Unicersity of Wïrzburg and ${ }^{2}$ Max-Planck-Institute for Psychiatry, Munich. F.R.G. \\ (Received 18 January 1991) \\ (Revision received 14 May 1991) \\ (Accepted 20 May 1991)
}

\section{Summary}

The mitogen-induced lymphocyte proliferative response and its sensitivity to in vitro $\left(10^{-10}-10^{-6} \mathrm{M}\right)$ dexamethasone (DEX) administration were investigated in 12 severely depressed patients and 13 healthy controls. Patients with major depressive disorder exhibited no impairment of lectin-induced blastogenesis, but a significantly weaker suppressive effect of in vitro DEX on $1.0 \mu \mathrm{g} / \mathrm{ml}$ phytohemagglutinin A-induced proliferation. The inhibitory potency of in vitro DEX was inversely correlated with in vivo adrenal cortical hormone levels at $4.00 \mathrm{p} . \mathrm{m}$. These effects were not observed with pokeweed mitogenand concanavalin A-stimulated cells. There were no correlations with age, weight, sex or severity of depression. These results do not support the hypothesis of a primarily impaired cell-mediated immunity, but might be indicative of reduced glucocorticoid receptor sensitivity in major depressive disorder.

Key words: Major depression; Lymphocyte transformation test; Glucocorticoids; Glucocorticoid receptor; Cell-mediated immunity

\section{Introduction}

In recent years, knowledge about the interactions between the brain, behavior and immunity has expanded rapidly (Ader et al., 1990). One well-studied mechanism of nervous system influ-

\footnotetext{
Address for correspondence: Dr. N. Wodarz, Department of Psychiatry, University of Würzburg, Füchsleinstr. 15, D-8700 Würzburg, F.R.G.

Tel.: 0931/203-1; Fax: 0931/203425.
}

ence on the immune system is regulation via adrenal cortical hormones. Both the experience of stressful life events and the syndrome of depression have been associated with alterations in circulating concentrations of glucocorticoids, as well as alterations in immune function (Calabrese et al., 1987; Irwin et al., 1987).

During acute depressive illness approximately $50 \%$ of patients were shown to have increased hypothalamic-pituitary-adrenal (HPA) axis activity, e.g., excess cortisol production and resistance 
to dexamethasone suppression (Carroll et al., 1968; Linkowski et al., 1985). Nevertheless, they fail to display clinical signs of Cushing's syndrome.

There might be a simple explanation for this phenomenon, such as a different duration and magnitude of hypercortisolism as compared to Cushing's syndrome. Since a variety of hormones are reported to be resistant to glucocorticoid-induced changes, e.g., adrenocorticotropic hormone (ACTH), $\beta$-endorphin and prolactin (Fang et al., 1981; Rupprecht et al., 1987, 1988), a glucocorticoid receptor dysfunction in major depressive disorder might be hypothesized. This again should have some effects on immune system integrity, since peripheral blood mononuclear cells possess glucocorticoid receptors and are sensitive to glucocorticoids (Cupps and Fauci, 1982).

Usually in vivo pharmacologic doses of glucocorticoids inhibit antigen- and mitogen-induced $\mathrm{T}$ lymphocyte proliferation and lymphokine production. In contrast, B lymphocytes are known to be sensitive to the suppressive effects of glucocorticoids only in the early activation phase of the cell cycle (Cupps and Fauci, 1982; Bowen and Fauci, 1984).

Most frequently, the mitogen response assay was used to determine the capacity of $T$ and $B$ lymphocytes to respond to antigens, i.e., the integrity of cell-mediated immunity. The commonly used lectins concanavalin A (Con A) and phytohemagglutinin $\mathrm{A}$ (PHA) are known to stimulate $\mathrm{T}$ lymphocytes quite selectively, whereas pokeweed mitogen (PWM) induces an accessory cell-dependent B lymphocyte proliferation (Rosenberg and Lipsky, 1979; Cupps and Fauci, 1982). Some groups have reported a significantly lower response to these lectins in lymphocytes of depressed patients compared to various control groups (Schlcifer et al., 1984; Calabrese et al., 1986; Kronfol et al., 1986; Cosyns et al., 1989). Other investigators were not able to replicate these findings (Albrecht et al., 1985; Darko et al., 1989; Schleifer et al., 1989) or even described an increase in response to PHA (Altshuler et al., 1989). Lowy et al. (1988) did not find any differences in basal lymphocyte responses between healthy controls, depressed and non-depressed psychiatric patients. Instead, they described a de- creased glucocorticoid sensitivity of Con Astimulated lymphocytes in depressed patients, who exhibited a positive dexamethasone suppression test (DST).

Despite its sensitivity to in vivo and in vitro glucocorticoids, the lectin-induced immune responses showed no correlation with the levels of circulating adrenal cortical hormones (Darko et al., 1989; Kronfol and House, 1989; Schleifer et al., 1989), nor with urinary free cortisol (Kronfol et al., 1986). But it has to be noticed that these studies differed quite considerably in methodology (e.g., concentrations of lectins, incubation period), as well as selection criteria of patients (e.g., diagnostic criteria, severity of depression, medication, age, sex).

This study addresses the following questions. (1) Is major depression (according to DSM-IIIR) associated with an impaired cell-mediated immunity? (2) Is major depression associated with an impairment of normal sensitivity of cell-mediated immunity to glucocorticoids? (3) Are the results associated with circulating concentrations of adrenal cortical hormones, such as cortisol and ACTH? (4) Are the results affected by the severity of depression or by several other variables, such as gender, age, weight?

\section{Methods}

\section{Patients}

Twelve subjects (mean age \pm SD: $48.7 \pm 15.1$ years; mean body weight $\pm \mathrm{SD}: 72.5 \pm 13.4 \mathrm{~kg}$ ), admitted to the psychiatric clinic of the University of Würzburg with severe unipolar major depressive disorder or bipolar depression (according to DSM-IIIR) and 13 non-hospitalized healthy controls, closely matched for age, sex and weight (mean age \pm SD: $47.4 \pm 6.4$ years; mean body weight \pm SD: $69.2 \pm 8.6 \mathrm{~kg}$ ) were studied. Four female depressives and the matched controls were tested during the midluteal phase of the cycle, the other females were postmenopausal.

All subjects were carefully screened for nutritional status and prevalence of medical illness, as well as alcohol or nicotine abuse and stressful life events that might influence pituitary-adrenal or immune system function, by medical history, physical examination and routine laboratory investigation. 
All patients were drug-free for at least 4 days prior to investigation, and seven patients for more than 3 weeks. DSM-IIIR (American Psychiatric Association, 1987) diagnoses were made independently by two psychiatrists, who were blind to laboratory investigations. Severity of depression was assessed on the day of laboratory investigation using the 21-item Hamilton Rating Scale for Depression (HRS-D; Hamilton, 1960).

Controls had no history of psychiatric disorder, nor had they relatives with a psychiatric illness. They were free of any medication and their HRSD scores were below 5 .

Written informed consent was obtained from all subjects prior to the investigation. This study was approved by the ethical committee of the University of Würzburg.

\section{Assays}

All subjects were admitted to a sleep laboratory unit at least $1 \mathrm{~h}$ prior to blood sampling. For determination of hormonal values and lymphocyte proliferation parameters $50 \mathrm{ml}$ venous blood was collected at 4.00 p.m. into plastic tubes containing EDTA.

\section{Preparation of cells}

Peripheral blood mononuclear cells (PBMC) were prepared from EDTA blood under sterile conditions by sodium metrizoate-Ficoll density gradient centrifugation as described previously (Rupprecht et al., 1990). Briefly, cells were washed twice in phosphate-buffered saline (PBS) at $100 \times \mathrm{g}$ for $10 \mathrm{~min}$ and incubated for $60 \mathrm{~min}$ at $37^{\circ} \mathrm{C}$, followed by a third washing procedure. The final cell count was performed with a Coulter counter (Model S5, Coulter Electronics Ltd, England). 'I 'he viability of cells exceeded $95 \%$, as judged from their ability to exclude trypan blue (Pappenheimer, 1917). Contamination by granulocytes and monocytes was always less than $8 \%$.

\section{Cell culture}

PBMC were suspended at a concentration of $2.5 \times 10^{4} /$ well in culture medium (see Chemicals) and incubated in triplicate in 96-well microtiter plates $(0.2 \mathrm{ml} /$ well; NUNC, Sweden $)$ for $60 \mathrm{~h}$ to evaluate Con A- and PHA-generated T cell proliferation and for $132 \mathrm{~h}$ to evaluate
PWM-generated accessory cell-dependent B cell proliferation in a sterile, humidified atmosphere $\left(5 \% \mathrm{CO}_{2} / 95 \%\right.$ air). To determine lectin dose-response curves, Con A and PWM were added at final concentrations of $0.5,1.0,5.0,10.0,20.0$, 40.0 and $50.0 \mu \mathrm{g} / \mathrm{ml}$, PHA at $0.1,0.5,1.0,2.5$, $5.0,10.0$ and $20.0 \mu \mathrm{g} / \mathrm{ml}$. Eventually, lectin-induced DNA synthesis in lymphocytes was analyzed at one optimal and one non-optimal concentration of each lectin (Table 2). To assess in vitro glucocorticoid sensitivity, $10^{-10}-10^{-6} \mathrm{~mol} / \mathrm{l}$ dexamcthasone (DEX) was added to spontancous (without lectin) and mitogen-stimulated lymphocyte cultures. Again one optimal and one non-optimal concentration of each lectin were used for mitogen-stimulated lymphocyte cultures.

To measure DNA synthesis $\left.0.5 \mu \mathrm{Ci}{ }^{3} \mathrm{H}\right]$ thymidine was added $5 \mathrm{~h}$ prior to termination of the incubation period. Incorporation of $\left[{ }^{3} \mathrm{H}\right]$ thymidine was assessed by rapid filtration through Whatman GF/B filters (Whatman, Maidstone, U.K.) with a Titertek semi-automatic cell harvester (Flow Laboratories, Inc., Rockville, MD, U.S.A.) by a 11-s wash with distilled water at room temperature. The radioisotope was measured by standard liquid scintillation counting in a Beckman LS 5000 TD counter at about 54\% efficiency. All samples were assayed in triplicate. The coefficient of variation was always less than $15 \%$.

\section{Serum hormone determinations}

ACTH was measured by a newly developed immunoradiometric assay (IRMA) supplied by the Nichols Institute (San Juan Capistrano, CA, U.S.A.; Raff and Findling, 1989). The lower detection limit was $1.5 \mathrm{pmol} / \mathrm{l}$, and the intra- and interassay coefficients of variation were $3 \%$ and $6.8 \%$, respectively.

Cortisol was measured by a direct radioimmunoassay (RIA) (Stalla et al., 1981). The lower detection limit was $25 \mathrm{nmol} / \mathrm{l}$, and the intra- and interassay coefficients of variation were $5 \%$ and $9 \%$, respectively.

\section{Chemicals}

$\left[{ }^{3} \mathrm{H}\right]$ Thymidine was obtained from Amersham, U.K. Phosphate-buffered saline (PBS) was obtained from Boehringer (Mannheim, F.R.G.). 
Concanavalin A (Con A), phytohemagglutinin A (PHA), pokeweed mitogen (PWM), dexamethasone and sodium metrizoate-Ficoll were obtained from Sigma (St. Louis, MO, U.S.A.), and Rotiszint 22 was obtained from Roth (Karlsruhe, F.R.G.). Con A, PHA, PWM and dexamethasone were diluted to the respective final concentrations with culture medium. The culture medium consisted of RPMI 1640 (Boehringer, Mannheim, F.R.G.) supplemented with $2 \mathrm{mM}$ L-glutamate (Biochrom, Berlin, F.R.G.), $0.1 \mathrm{mg} / \mathrm{ml}$ gentamicin (Biochrom, Bcrlin, F.R.G.) and $10 \%$ fetal calf serum (FCS, Biochrom, Berlin, F.R.G.). The same lots of lectins and FCS were used throughout the whole investigation to limit methodological variation.

\section{Statistical analysis}

Lymphocytc prolifcration was expressed in terms of a stimulation index (SI) defined by the ratio of stimulated (in the presence of lectin) counts per minute (cpm) to spontaneous (in the absence of lectin) $\mathrm{cpm}$. The results are mean \pm SD, unless otherwise stated. Hormone values below the detection limit of our assays were recorded as the respective detection limits. Data were analyzed using Pearson's product-moment correlation, one-way analysis of variance
(ANOVA), and analysis of covariance (ANCOVA). All significance levels are two-tailed.

\section{Results}

Cell riability

Under the culture conditions of the lymphocyte proliferation assays, the mean cell viabilities at the time of harvest (day 3 and day 5) were $97.0 \% \pm 1.3 \%$ and $94.8 \% \pm 2.5 \%$, respectively.

\section{Descriptice statistics}

Table 1 summarizes the demographic and clinical data of the 12 depressive patients studied. There were no significant differences in age, weight or hormone values between the controls and depressed patients investigated.

No significant correlations could be seen between age, weight, HRS-D score and hormone values.

Cortisol and ACTH values were not significantly correlated in patients with major depressive disorder $(r=0.387, P=0.24, n=12)$, but nearly reached statistical significance in controls ( $r=0.520, \quad P<0.07, n=13$ ). Due to the increased number of cases it reached significance in the whole cohort of subjects $(r=0.451, P<0.03$, $n=25$ ).

TABLE 1

DEMOGRAPHIC AND CLINICAL DATA OF THE 12 DEPRESSIVE PATIENTS STUDIED

\begin{tabular}{|c|c|c|c|c|c|c|}
\hline $\begin{array}{l}\text { Age } \\
\text { (years) }\end{array}$ & Sex & DSM-IIIR & $\overline{\text { HRS-D }}$ & $\begin{array}{l}\text { Depressive } \\
\text { episodes }\end{array}$ & $\begin{array}{l}\text { Drug-free } \\
\text { period } \\
\text { (days) }\end{array}$ & $\begin{array}{l}\text { Medication } \\
\text { prior to drug- } \\
\text { fiee period }\end{array}$ \\
\hline 44 & $\mathrm{~F}$ & 296.53 & 33 & 3 & $>28$ & \\
\hline 66 & $\mathrm{~F}$ & 296.33 & 36 & 2 & $>28$ & \\
\hline 61 & $\mathrm{~F}$ & 296.34 & 28 & 3 & $>28$ & \\
\hline 64 & $\mathrm{~F}$ & 296.33 & 28 & 4 & $>28$ & \\
\hline 39 & $\mathrm{~F}$ & 296.33 & 25 & 3 & 7 & $100 \mathrm{mg} \mathrm{ami}$ \\
\hline 60 & $\mathrm{M}$ & 296.33 & 24 & 3 & 5 & $100 \mathrm{mg} \mathrm{ami}$ \\
\hline 60 & $\mathrm{M}$ & 296.33 & 28 & 3 & 5 & $150 \mathrm{mg}$ map \\
\hline 34 & $F$ & 296.33 & 28 & 3 & 4 & $100 \mathrm{mg}$ map \\
\hline 54 & $\mathrm{~F}$ & 296.53 & 33 & 6 & $>28$ & \\
\hline 18 & $F$ & 296.23 & 26 & 1 & $>28$ & \\
\hline 5.3 & $\mathrm{M}$ & 296.33 & 26 & 2 & $>21$ & \\
\hline 34 & $\mathrm{~F}$ & 296.33 & 39 & 3 & 5 & $150 \mathrm{mg} \mathrm{ami}$ \\
\hline $48.7 \pm 15.1$ & & & $29.5 \pm 4.7$ & $3.0 \pm 1.2$ & & Mcan $\perp$ SD \\
\hline
\end{tabular}

ami, amitriptyline; map, maprotiline. 
TABLE 2

HORMONE VALUES AND LYMPHOCYTE PROLIFERATIVE RESPONSE OF DEPRESSIVE PATIENTS AND CONTROLS

\begin{tabular}{|c|c|c|}
\hline & $\begin{array}{l}\text { Controls } \\
(n=13)\end{array}$ & $\begin{array}{l}\text { Patients } \\
(n=12)\end{array}$ \\
\hline Cortisol (pmol/l) & $225.7 \pm 77.3$ & $273.1 \pm 104.8$ \\
\hline ACTH $(\mathrm{pmol} / \mathrm{l})$ & $3.6 \pm 0.8$ & $4.2 \pm \quad 1.5$ \\
\hline \multicolumn{3}{|l|}{$\begin{array}{l}\text { Stimulation indices } \\
\text { optimal }\end{array}$} \\
\hline $10.0 \mu \mathrm{g} / \mathrm{ml} \mathrm{PHA}$ & $28.0 \pm 5.0$ & $23.4 \pm \quad 3.9$ \\
\hline $10.0 \mu \mathrm{g} / \mathrm{ml} \operatorname{Con} \mathrm{A}$ & $15.1+2.4$ & $14.7+2.1$ \\
\hline $\begin{array}{l}10.0 \mu \mathrm{g} / \mathrm{ml} \mathrm{PWM} \\
\text { non-optimal }\end{array}$ & $17.5 \pm 3.1$ & $21.9 \pm \quad 4.2$ \\
\hline $1.0 \mu \mathrm{g} / \mathrm{ml}$ PHA & $9.2 \pm 1.4$ & $9.4 \pm 1.6$ \\
\hline $1.0 \mu \mathrm{g} / \mathrm{ml} \operatorname{Con} \mathrm{A}$ & $5.6 \pm 0.9$ & $4.0 \pm \quad 0.5$ \\
\hline $1.0 \mu \mathrm{g} / \mathrm{ml} \mathrm{PWM}$ & $11.7 \pm 2.4$ & $15.9 \pm \quad 2.7$ \\
\hline
\end{tabular}

Stimulation index: ratio of lectin-stimulated to spontaneous cpm.

\section{I.ectin-induced lymphocyte blastogenesis}

Table 2 shows the hormone values and lymphocyte blastogenesis after stimulation with one optimal and one non-optimal concentration of each lectin. There was no statistically significant difference between depressed patients and controls in lymphocyte response to any concentration of the lectins tested.

No significant correlations could be observed between the lymphocyte responses to PWM, Con A or PHA and age, weight, HRS-D score or cortisol values. Only lymphocyte blastogenesis after stimulation with the non-optimal PHA concentration $(1.0 \mu \mathrm{g} / \mathrm{ml})$ was significantly associated with ACTH values in depressed patients $(r=-0.66, P<0.04)$.

Sensitivity of lymphocyte blastogenesis to in vitro added dexamethasone

In vitro added DEX produced a dose-dependent suppression of spontaneous, PHA- (Figs. 1, 2) and Con A-induced lymphocyte proliferative responses (not shown) in patients and healthy controls. In vitro DEX administration exhibited no suppressive effect on PWM-stimulated blastogenesis in either group (Fig. 3).

In all subjects serum cortisol levels at 4.00 p.m. were significantly associated with the inhibitory potency of in vitro DEX on $1.0 \mu \mathrm{g} / \mathrm{ml} \mathrm{PHA-}$

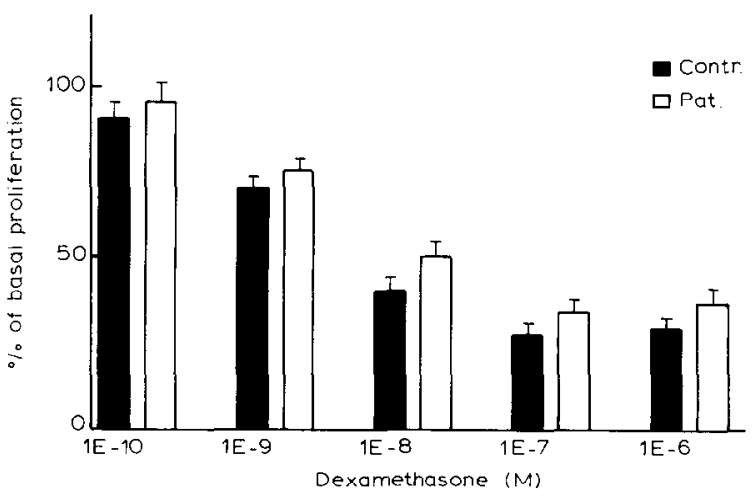

Fig. 1. Effect of $10^{-10}-10^{-h} \mathrm{M}$ in vitro dexamethasone on 1.0 $\mu \mathrm{g} / \mathrm{ml}$ PHA-induced lymphocyte blastogenesis (arithmetic means $\pm S D$; all assays were performed in triplicate). After covarying out serum cortisol levels, the differences between healthy controls $(n=13)$ and depressive patients $(n=12)$ were statistically significant ( $P<0.05$; see Results for details).

stimulated cells (Table 3). ACTH levels were only correlated with the inhibition of PHA-induced proliferation by $10^{-10}-10^{9} \mathrm{~mol} / 1$ DEX (Table 3). The results with $10.0 \mu \mathrm{g} / \mathrm{ml}$ PHA-stimulated cells are shown in Table 3.

No significant correlations could be observed between levels of adrenal cortical hormones and DEX-induced inhibition of cells stimulated with optimal or non-optimal concentrations of Con A and PWM.

Since the in vitro PHA-stimulated lymphocyte proliferative response was correlated with the in vivo hormone levels (Table 3), it seemed useful to

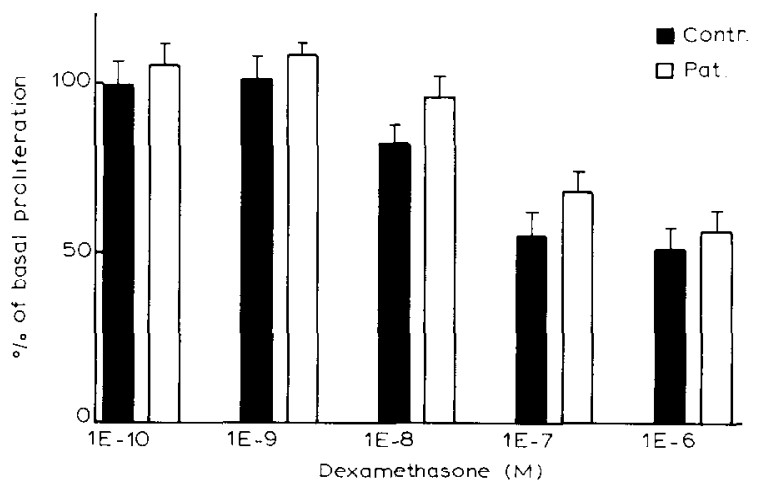

Fig. 2. Effect of $10^{-10}-10^{-6} \mathrm{M}$ in vitro dexamethasone on $10.0 \mu \mathrm{g} / \mathrm{ml}$ PHA-induced lymphocyte blastogenesis (arithmetic means $\pm \mathrm{SD}$; all assays were performed in triplicate). The differences between healthy controls $(n=13)$ and depressive patients $(n=12)$ were statistically not significant. 


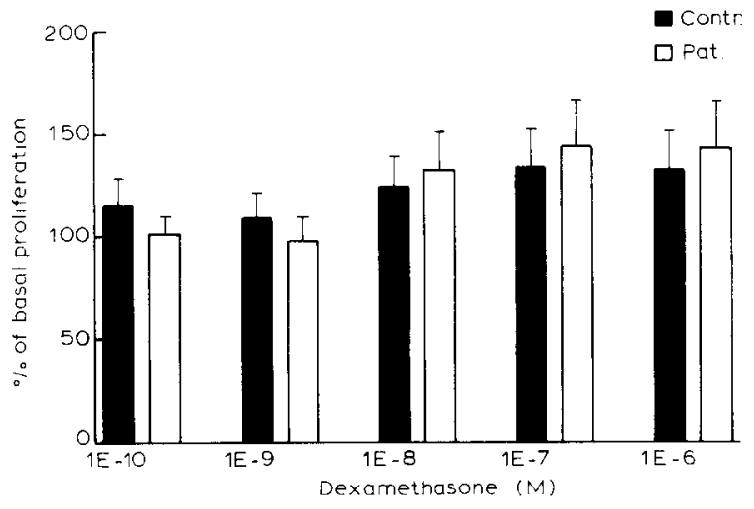

Fig. 3. Effect of $10^{-10}-10^{-6} \mathrm{M}$ in vitro dexamethasone on $10.0 \mu \mathrm{g} / \mathrm{ml}$ PWM-induced lymphocyte blastogenesis (arithmetic means $\pm \mathrm{SD}$; all assays were performed in triplicate). The differences between healthy controls $(n=13)$ and depressive patients $(n=12)$ were statistically not significant.

weigh this influence statistically. Therefore, individuals' in vitro lymphocyte proliferation was adjusted for their in vivo cortisol levels (ANCOVA). This revealed that $1.0 \mu \mathrm{g} / \mathrm{ml}$ PHA-stimulated lymphocytes of depressed patients exhibited a significantly weaker suppression of blastogenesis after in vitro addition of $10^{-8} \mathrm{~mol} / \mathrm{l}(F=4.49$, $P<0.04), 10^{-7} \mathrm{~mol} / \mathrm{l}(F=6.09, P<0.03)$ and $10^{-6} \mathrm{~mol} / 1 \mathrm{DEX}(F=6.61, P<0.02)$. The same results could be obtained after serum ACTH levels were covaried out $\left(10^{-8} \mathrm{~mol} / \mathrm{l}: F=5.11\right.$, $P<0.04 ; 10^{-7} \mathrm{~mol} / \mathrm{l}: F=3.99, \quad P<0.05 ; 10^{-6}$ mol $/ 1$ DEX: $F=5.52, P<0.03$ ). Only a non-significant trend $(P=0.1)$ could be seen with 10.0 $\mu \mathrm{g} / \mathrm{ml}$ PHA-stimulated lymphocytes.

\section{TABLE 3}

CORRELATIONS $(r)$ BETWEEN ACTH AND CORTISOL LEVELS AND PHA-STIMULATED LYMPHOCYTE BLASTOGENESIS

\begin{tabular}{|c|c|c|c|c|}
\hline \multirow{2}{*}{$\begin{array}{l}\mathrm{DEX} \\
{[\mathrm{mol} / \mathrm{l}]}\end{array}$} & \multicolumn{2}{|c|}{$1.0 \mu \mathrm{g} / \mathrm{ml}$ PHA } & \multicolumn{2}{|c|}{$10.0 \mu \mathrm{g} / \mathrm{ml} \mathrm{PHA}$} \\
\hline & Cortisol & ACTII & Cortisol & ACTH \\
\hline$\overline{10^{-10}}$ & $-0.45^{*}$ & $-0.52 *$ & -0.23 & -0.34 \\
\hline $10^{-9}$ & $-0.42 *$ & $-0.45 *$ & -0.32 & $-0.39 * *$ \\
\hline $10^{-x}$ & $-0.44 *$ & $-0.37 * *$ & -0.26 & $-0.35 * *$ \\
\hline $10^{-7}$ & $-0.50 *$ & -0.22 & $-0.39 * *$ & $-0.38 * *$ \\
\hline $10^{-6}$ & $-0.52 *$ & -0.34 & $-0.41 * *$ & $-0.37 * *$ \\
\hline
\end{tabular}

$N=25$.

$* P<0.05: * * \mathrm{P}<0.1$.
No significant differences in DEX sensitivity of PWM- and Con A-stimulated lymphocytes could be detected between the two groups, even after covarying out the influence of in vivo hormone values.

\section{Discussion}

In accordance with Albrecht et al. (1985), Darko et al. (1989) and Schleifer et al. (1989) we were not able to corroborate previous findings of primarily impaircd cell-mediated immunity in depressed patients by means of the lymphocyte transformation assay (Schleifer et al., 1984; Calabrese et al., 1986; Kronfol et al., 1986; Cosyns et al., 1989). There were no differences in PWM-, PHA- or Con A-induced proliferative responses between patients with major depressive disorder and healthy controls.

Schleifer et al. (1989) attributed impaired lectin-induced lymphocyte blastogenesis to factors such as age or severity of depression. However, in accordance with other groups (Albrecht et al., 1985; Kronfol et al., 1986; Cosyns et al., 1989) we were not able to confirm such an association. Moreover, in contrast to Schleifer et al. (1989), we could not observe a significant contribution of severity of depression, as assessed by the 21-item HRS-D, or of several independent variables, such as gender, age or weight.

These discrepancies might be due to our relatively homogeneous and small group of severely depressed paticnts, as well as to differences in the methodology applied.

Previous studies took blood samples in the morning hours, when the level of cortisol reaches its circadian peak (Ritchie et al., 1983). Glucocorticoid receptors are supposed to be down-regulated in the morning hours and up-regulated in the cvening (Rupprecht et al., 1990). Therefore, glucocorticoid-induced effects might be more evident when blood samples are taken in the afternoon hours. This also indicates that single-point measurements of circulating hormones might not exactly reflect the blood concentrations over the previous several hours, which primarily determine receptor sensitivity.

The circadian variation of lymphocyte subpopulations is well established, as well as their differ- 
ent sensitivity to glucocorticoids (Ritchie et al., 1983). Moreover, stimulation of $\mathrm{T}$ lymphocyte subpopulations is thought to depend partly on the lectin and on the concentrations used (Dwyer and Johnson, 1981). Thereforc, the circadian rhythm of $T$ cell subsets in the peripheral blood and their different sensitivity to glucocorticoids might be a reason for the discrepant results after stimulation with the T cell mitogens PHA and Con A.

Data in previous work (with the exception of Darko et al., 1989) have been expressed as stimulated (in the presence of lectin) cpm minus spontaneous (in the absence of lectin) cpm. In contrast, we analyzed lymphocyte proliferation in terms of a stimulation index, which weighs in vitro proliferation of in vivo stimulated cells more heavily and has a lower interassay coefficient of variation.

Although our patients with major depressive disorder tended to have higher cortisol values than healthy controls, this did not reach statistical significance. In accordance with other investigators (Albrecht et al., 1985; Kronfol et al., 1986) we were not able to observe a correlation between primary in vitro lymphocyte blastogenesis and in vivo levels of adrenal cortical hormones.

Interestingly, the DEX-induced inhibition of PHA-stimulated blastogenesis was inversely correlated with adrenal cortical hormone values. Consequently, high levels of circulating cortisol in vivo result in a desensitization of the glucocorticoid receptor. This supports previous findings from our and other laboratories that the glucocorticoid receptor is under autoregulatory control in humans (Lowy et al., 1988; Rupprecht et al., 1990). Moreover, after covarying out the influence of in vivo hormone levels, PHA-stimulated lymphocytes of depressed patients exhibited an impaired sensitivity to pharmacological as well as physiological concentrations of in vitro glucocorticoids.

These results are partly in contrast to those of Lowy et al. (1988), who also described a weaker DEX-induced suppression of lymphocyte blastogenesis, but only after stimulation with Con A. This discrepancy might be mainly attributed to the above-mentioned methodological differences (e.g., time of blood sampling and concentrations of lectins), as well as to differences in selection criteria of patients (e.g., dexamethasone suppressors and non-suppressors).

Our data suggest that in depressed patients immune system integrity could usually be maintained by adaptation to the endogenous hypercortisolemia. But this fragile new homeostasis might be difficult to maintain if additional disturbances occur (e.g., pharmacologically induced or physiological shifts of in vivo hormonal balance). This might further support the hypothesis of a glucocorticoid receptor dysfunction in patients with major depressive disorder, since a variety of hormones are reported to be resistant to glucocorticoid-induced changes during the acute phase of the disease, as well (Fang et al., 1981; Rupprecht et al., 1987, 1988). Moreover, some recent reports have described that antidepressants elicit an increase of glucocorticoid receptor mRNA and immunoreactivity in neuronal cell cultures and in the locus coeruleus of rats (Pepin et al., 1989; Kitayama et al., 1988).

In conclusion, the elucidation of the exact mechanism of impaired glucocorticoid sensitivity (i.e., abnormalities in glucocorticoid receptor activation, translocation, genomic interaction, expression of proteins, etc.) may yield insights into the pathophysiology of major depressive disorder. Therefore, further analysis of glucocorticoid receptor function (e.g., by means of in vivo and in vitro challenge studies) is needed to more clearly delineate the relationship among the hypothesized impaired receptor plasticity, derangement of HPA axis activity and major depressive disorder.

\section{References}

Ader, R., Felten, D. and Cohen, N. (1990) Interactions between the brain and the immune system. Annu. Rev. Pharmacol. Toxicol. 30, 561-602.

Albrecht, J., Helderman, J.H., Schlesser, M.A. and Rush, A.J. (1985) A controlled study of cellular immune function in affective disorders before and during somatic therapy. Psychiatry Res. 15, 185-193.

Altshuler, L.L., Plaeger Marshall, S., Richeimer, S., Daniels, M. and Baxter, L.R. Jr. (1989) Lymphocyte function in major depression. Acta Psychiatr. Scand. 80, 132-136.

American Psychiatric Association (1987) Diagnostic and Statistical Manual of Mental Disorders, 3rd edn. revised. American Psychiatric Association, Washington, DC. 
Bowen, D.L. and Fauci, A.S. (1984) Selective suppressive effects of glucocorticoids on the early events in the human B cell activation process. J. Immunol. 133, 1885-1890.

Calabrese, J.R., Skwerer, R.G., Barna, B., Gulledge, A.D., Valenzuela, R., Butkus, A., Subichin, S. and Krupp, N.E. (1986) Depression, immunocompetence, and prostaglandins of the E series. Psychiatry Res. 17, 41-47.

Calabrese, J.R., Kling, A.C. and Targum, S.D. (1987) Alterations in immunocompetence during stress, bereavement, and depression: focuses on neuroendocrine regulation. Am. J. Psychiatry 144, 1123-1134.

Carroll, B.J., Martin, F.I. and Davis, B.M. (1968) Resistance to suppression by dexamethasone of plasma 11-OHCS levels in severe depressive illness. Br. Med. J. 3, 285-287.

Cosyns, P., Maes, M., Vandewoude, M., Stevens, W.J., De Clerck, L.S. and Schotte, C. (1989) Impaired mitogen-induced lymphocyte responses and the hypothalamic pituitary-adrenal axis in depressive disorders. J. Affect. Disord. $16,41-48$.

Cupps, T.R. and Fauci, A.S. (1982) Corticosteroid-mediated immunoregulation in man. Immunol. Rev. 65, 133-155.

Darko, D.F., Gillin, J.C., Risch, S.C., Bulloch, K., Golshan, S., Tasevska, Z. and Hamburger, R.N. (1989) Mitogen-stimulated lymphocyte proliferation and pituitary hormones in major depression. Biol. Psychiatry 26, 145-155.

Dwyer, J.M. and Johnson, C. (1981) The use of concanavalin A to study the immunoregulation of human T cells. Clin. Exp. Immunol. 46, 237-249.

Fang, V.S., Tricou, B.J., Robertson, A. and Meltzer, H.Y. (1981) Plasma ACTH and cortisol levels in depressed patients: relation to the dexamethasone suppression test. Life Sci. 29, 931-938.

Hamilton, M. (1960) A rating scale for depression. J. Neurol. Neurosurg. Psychiatry 23, 56-62.

Irwin, M., Daniels, M., Bloom, E.T., Smith, T.L. and Weiner, H. (1987) Life events, depressive symptoms, and immune function. Am. J. Psychiatry 144, 437-441.

Kitayama, I., Janson, A.M., Cintra, A., Fuxe, K., Agnati, L.F., Ögren, S.O., Härfstrand, A., Eneroth, P. and Gustafsson, J.A. (1988) Effects of chronic imipramine treatment on glucocorticoid receptor immunoreactivity in various regions of the rat brain. J. Neural. Transm. 73, 191-203.

Kronfol, Z. and House, J.D. (1989) Lymphocyte mitogenesis, immunoglobulin and complement levels in depressed patients and normal controls. Acta Psychiatr. Scand. 80, 142-147.

Kronfol, Z., House, J.D., Silva, J. Jr., Greden, J. and Carroll, B.J. (1986) Depression, urinary free corlisol excretion and lymphocyte function. Br. J. Psychiatry 148, 70-73.

Linkowski, P., Mendlewicz, J., Leclercq, R., Brasseur, M., Hubain, P., Golstein, J., Copinschi, G. and van Cauter, E.
(1985) The 24-hour profile of adrenocorticotropin and cortisol in major depressive illness. J. Clin. Endocrinol. Metab. 61, 429-438.

Lowy, M.T., Reder, A.T., Gormley, G.J. and Meltzer, H.Y. (1988) Comparison of in vivo and in vitro glucocorticoid seusitivity in depression: relationship to the dexamethasone suppression test. Biol. Psychiatry 24, 619-630.

Pappenheimer, A.M. (1917) Experimental studies upon lymphocytes: 1. The reactions of lymphocytes under various experimental conditions. J. Exp. Med. 25, 633-636.

Pepin, M.C., Beaulieu, S. and Barden, N. (1989) Antidepressants regulate glucocorticoid receptor messenger RNA concentrations in primary neuronal cell cultures. Mol. Brain Res. 6, 77-83.

Raff, H. and Findling, J.W. (1989) A new immunoradiometric assay for corticotropin evaluated in normal subjects and in patients with Cushing's disease. Clin. Chem. 35, 596-600.

Ritchie, A.W.S., Oswald, I., Micklem, H.S., Boyd, J.E., Elton, R.A., Jazwinska, E. and James, K. (1983) Circadian variation of lymphocyte subpopulations: a study with monoclonal antibodies. Br. Med. J. 286, 1773-1775.

Rosenberg, S.A. and Lipsky, P.E. (1979) Monocyte dependence of pokeweed mitogen-induced differentiation of immunoglobulin-secreting cells from human peripheral blood mononuclear cells. J. Immunol. 122, 926-931.

Rupprecht, R., Barocka, A., Jecht, E., Noder, M., Pichl, J. and Schwarz, M. (1987) Prolactin response to dexamethasone: a study on normal controls and depressed patients. Acta Psychiatr. Scand. 76, 139-143.

Rupprecht, R., Barocka, A., Beck, G., Schrell, U. and Pichl, J. (1988) Pre- and postdexamethasone plasma ACTH and $\beta$-endorphin levels in endogenous and non-endogenous depression. Biol. Psychiatry 23, 531-535.

Rupprecht, R., Kornhuber, J., Wodarz, N., Göbel, C., Lugauer, J., Sinzger, C., Müller, O.A. and Riederer, P. (1990) Characterization of glucocorticoid receptor binding capacity in human mononuclear leukocytes: increase by metyrapone is prevented by dexamethasone pretreatment. J. Neuroendocrinol. 2, 803-806.

Schleifer, S.J., Keller, S.E., Meyerson, A.T., Raskin. M.J., Davis, K.L. and Stein, M. (1984) Lymphocyte function in major depressive disorder. Arch. Gen. Psychiatry 41, 484486.

Schleifer, S.J., Keller, S.E., Bond, R.N., Cohen, J. and Stein, M. (1989) Major depressive disorder and immunity. Role of age, sex, severity, and hospitalization. Arch. Gen. Psychiatry $46,81-87$.

Stalla, G.K., Giesemann, G., Müller, O.A., Wood, W.G. and Scriba, P.C. (1981) The development of a direct homologous radioimmunoassay for serum cortisol. J. Clin. Chem. Clin. Biochem. 19, 427-434. 